\title{
Monday Effect Analysis On LQ45 Share Return in Indonesia Stock Exchange
}

\author{
Tigris Asyur Sipahutar, Hakiman, Dr, MM \\ Department of Management, Universitas Mercu Buana, Jakarta, Indonesia \\ grisgiest@gmail.com \\ hakiman.thamrin@mercubuana.ac.id \\ DOI: 10.29322/IJSRP.11.05.2021.p11306 \\ http://dx.doi.org/10.29322/IJSRP.11.05.2021.p11306
}

\begin{abstract}
This study aims to analyze the Monday effect on LQ-45 stock returns. The sample used in this study is daily stock return data f companies that are included in LQ45 for the period August 2019 to January 2020, totaling 45 companies. The data analysis technique used is one t- test. The result showed that: (1) There is a significant difference between daily stock returns on trading days in one week on the Indonesia Stock Exchange. (2) There is a Monday Effect on stock trading on the Indonesia Stock Exchange.
\end{abstract}

Keywords: finance, management, Monday effect, return, LQ45

\section{PRELIMINARY}

Investors, before giving a choice of which stocks to invest in, make an assessment of the selected stocks in order to know the risk (risk) and return (return). Risk can be said to be a form of uncertainty about a situation that will later occur related to decisions made at this time based on various considerations.

Return is the profit received by a stock valuation company that can be done with technical analysis, namely paying attention to past movements in stock prices or returns. Understand. Investors expect an increase in return every time a transaction has been made at least $50 \%$ of the investment level. Technical analysis can be done with an investment approach, namely studying historical data from stock prices at that time and linking it to the trading volume that occurs and economic conditions. It's just that technical analysis pays attention to the performance of the companies that issue these shares. There are many stock returns that do not reflect the appropriate information. The problems that occur are due to securities prices that do not describe all the information properly, resulting in an inefficient market. There are phenomena, irregularities, or anomalies that are obtained according to research on efficient capital markets.

Investors expect above-normal returns for each investment. Every investor uses a trading strategy, for example anomalies that often occur in markets that are used by investors. In market anomalies, the results that arise will be contrary to the results expected in an efficient capital market. Market anomaly is the cause of an inefficient market. Market anomalies are in the opposite way to the concept of efficient capital markets. The efficient market hypothesis is that the price of securities has described all of the information available so that there is no opportunity for investors to consistently get abnormal returns. There are four types of anomalies, namely event anomalies, seasonal anomalies, company anomalies and accounting anomalies. Of the four anomalies, seasonal anomalies are the ones that often occur. Seasonal anomaly is a market anomaly whose existence depends on time. With this seasonal anomaly, investors will find it easy to predict returns at a certain time so that a pattern of stock price movements can be predicted by investors and there is a possibility for investors to use this pattern to obtain abnormal returns. The market anomalies that are most often used as research are seasonal anomalies consisting of the Monday Effect, Weekend Effect Week Four Effects, January effect, The Month of the year effect, Turn of the year effect, Holiday Effect, and the Rogalsky Effect.

Of all the phenomena of seasonal anomalies, the most frequently used research is the Monday Effect, Weekend Effect and Week Four Effect phenomenon because this phenomenon is closer to financial reports because to determine the desired return, it is necessary to analyze the return on Monday. 
Psychological factors determine the Monday effect phenomenon which causes irrational behavior in which emotional factors, psychological behavior, and investor desires influence economic decisions. The worst day is Monday when compared to other days of the week because it is the first day of work and vice versa, Friday is the best day due to the last working day before the holiday. This is what makes investors tend to feel pessimistic on Monday and on Friday to feel optimistic. This irrational behavior makes Monday's return on average negative. Issuers that announce on the last day of bad news for stock trading also make stock returns on Monday tend to be negative. Investors sold their shares as quickly as possible Monday when they learned of bad news for the company.

From the above background, the authors are interested in examining the phenomenon of the Monday effect of stocks on stock trading on the Indonesia Stock Exchange, with the research title "Analysis of Monday Effect on LQ45 Company Stock Returns on the Indonesia Stock Exchange".

Researchers take the formulation of the problem as follows:

1. Is there a difference in LQ45 company stock returns Monday to Friday on the Indonesia Stock Exchange during August 2019 to January 2020?

2. Was there a Monday effect on the trading of LQ 45 shares?

Benefits of research

As for the benefits of this research for investors and potential investors to analyze the investment and investment decisions to be made. The information obtained is in the form of stock price variability behavior. In addition, the benefit of this research is the presentation of the reliability of return information in relation to the decisions made by investors and for potential investors.

Research purposes

Knowing the effect of the Monday Effect on the LQ45 company stock return on the Indonesia Stock Exchange.

\section{THEORITICAL REVIEW}

The first time the efficiency market theory was discovered in a study conducted by Bachelier in 1900 to determine whether stock prices fluctuate randomly or not. Then in 1905 Pearson introduced a random-walk pattern, known as the drunkardwalk concept. Bachelier's research and Pearson's drunkardwalk concept were ignored and no further study was carried out until the 1930s. Kendall in 1953, in the financial literature used and introduced the term random-walk. Then, Fama discussed some empirical evidence that supports the random-walk theory in his doctoral dissertation and pioneered the emergence of the EMH (Efficiency Market Hypothesis) theory in 1970. Fama introduced the EMH theory into a theory that is widely used as a basis for research related to market anomalies.

Several definitions related to market efficiency are summarized by Belkaoui from the experts:

a. Fama in 1970 said "in an efficient market the price will fully reflect the available information and the implication is that prices will react immediately without bias to new information".

b. Beaver (1989) states that "market efficiency is the relationship between stock securities prices and the availability of information".

Based on this definition, the efficient market concept is closely related to the availability of information. A market is said to be efficient if the value of a security at any time reflects all available information and results in the price of a security at its equilibrium level. The balance of the price of a security results in no opportunity for investors to get an abnormal return from the difference in the price of stock securities.

As for some of the characteristics of an efficient market, namely:

a. Investors are price takers, meaning that as market participants, investors alone cannot influence the price of a security.

b. Information is widely available to all market participants at the same time and the price for obtaining such information is cheap. 
c. The information is generated randomly and each information announcement is random from one another so investors cannot predict when the issuer will announce new information.

d. Investors react to the information in full and quickly, so that the price of the security changes accordingly to reflect the information to reach a new equilibrium.

As for some of the characteristics of an inefficient market, if the following conditions occur:

a. There are a small number of market participants who can influence the price of a security.

b. The high price of information and the unequal access to information between one market participant and another.

c. The dissemination of information can be predicted well by some of the actors.

Investors are naive investors and unsophisticated individuals.

In 1970, Fama divided market efficiency into three main forms, namely:

1. Weak form market efficiency (weak form)

A market that is said to be efficient in a weak form is when the prices of stocks or securities fully reflect information from the past. Information is said to be the past if that information has already occurred. The weak form of market efficiency is closely related to the random walk theory which says past data cannot be linked to present values. This means that past values cannot be used to predict current prices.

2. Market efficiency of semi strong form (semistrong form)

A semi-strong efficient market is defined as if the prices of share securities fully reflect all published information (all publicly available information) including information contained in financial reports.

\section{Market efficiency strong form (strong form)}

What is said to be an efficient market is in a strong form if the prices of stock securities fully reflect all available information, including even highly confidential information. If the market is efficient in this form, it means an individual investor or a group of investors who gets an abnormal return.

Several Types of Market Anomalies

There are several known seasonal anomalies, including:

\section{January effect}

Namely the influence of the calendar where the return in January is higher than other months, and small cap stocks (small stock) tend to increase in price in January compared to other months. The abnormal returns in January for small stocks were generally higher in the early days of the month. According to Sharpe, Alexander, and Bailey (2005), the hypothesis that explains the January effect is tax loss selling, window dressing and small stock's beta. Tax loss selling is selling underperforming stocks at the end of the year to reduce the amount of tax borne, so that in December the share price will fall, then buy back in January which causes the stock price to rise again in January. Window dressing is not too different from tax loss selling, namely the sale of stocks that had a bad performance at the end of the year. The difference is that window dressing is carried out by financial managers or institutional investors.

2. The day of week effect

The phenomenon of seasonal anomaly where there is a difference in return for each day and the effect of trading days in one week. The stock price will increase or decrease in different days of the trading day week. Known variations of this anomaly include the Monday effect and the weekend effect.

\section{Monday effect}

Monday effect occurs when Monday returns tend to produce negative returns. Monday effect is part of the day of the week effect. The Monday effect phenomenon occurs due to the influence of irrational patterns of investor behavior in trading on Monday. 


\section{Weekend effect}

Weekend Effect is a phenomenon where the return on the last day of the trading week has a positive return. The weekend effect is known as the Friday effect for the stock market, the last day of the trading week, which is Friday. Where the return on Friday is more likely to be positive.

\section{Week four effect}

Week four effect is a phenomenon which reveals that the Monday effect only occurs in the last weeks of each month, namely the fourth and fifth weeks, while Monday returns from the first week to the third week are considered insignificant negative or equal to zero.

\section{The month of year effect}

The month of year effect is a seasonal anomaly where there is a significant difference in stock returns each month in one year. Within a certain month, stock returns have a positive and significant effect. There are several hypotheses that give rise to this phenomenon, such as the tax reporting period, financial report issuance, fiscal year end, stock supply and demand.

\section{Turn of the month effect}

Turn of the month effect is an anomaly where the rate of return at the beginning of the month is always higher (positive) when compared to the end of the month which reaches negative. The day at the turn of the month is often interpreted as the last day of the month up to the first three days of the following month. According to Mulyono (2009), one of the hypotheses that can provide an explanation for this anomaly is liquidity trading, which is a demand for securities in the market by individual investors who experience an increase at the beginning of the month due to receiving salary payments, then investing by buying securities in the market.

\section{Turn of the year effect}

The turn of the year effect is a calendar anomaly that illustrates an increase in trading volume and stock prices at the end of December and in the first two weeks of January. This phenomenon is often known as the end of December effect and also collaborates with the January effect.

\section{Holiday effect}

The holiday effect is that there is a tendency for the average stock return on one day before a holiday (pre holiday return) to be higher and the stock return on the day after a holiday (post holiday return) is lower than the normal daily return rate.

\section{Rogalski effect}

Rogalski effect is a phenomenon discovered by a researcher named Rogalski in 1984, where the negative daily return that usually occurs on Monday (Monday effect) disappears in certain months

\section{Stock returns}

Stock return is a result of investment or the level of profit enjoyed by investors or the investment made, the return is calculated from the actual return expected consisting of capital gain and dividend yield. Capital gain is the difference between the selling price and the buying price per share divided by the purchase price, and the dividend yield is the dividend per share divided by the purchase price per share. Stock return or share return is the rate of return on common stock, and is a cash payment received as a result of ownership. Stock return is the expected rate of return on the investment that has been made. Return is the result obtained from investment. Returns can be in the form of realized returns that have occurred or expected returns that have not occurred but which are expected to occur in the future. Realized return is the return that has occurred. Realized returns are calculated based on historical data. Return realization is important because it is a measure of the company's performance. This historical return is also useful as a basis for determining the expected return and risk in the future. Expected return is the return expected by investors in 
the future. The rate of return or return on an investment is measured as the total profit or loss received by the investor (owner) during a certain period.

The calculation of stock returns, namely:

$\mathrm{Rt}=((\mathrm{Pt}-\mathrm{Pt}-1)) /(\mathrm{Pt}-1)$

Information:

$\mathrm{Pt}=$ closing price of shares at the end of period $\mathrm{t}$

Pt-1 = closing price of shares at the end of period $\mathrm{t}-1$

\section{LQ45 Index}

The Indonesian capital market is classified as a capital market whose transactions are thin (thin market), namely a capital market where most of the securities are less actively traded. So on February 24, 1997 another alternative index was introduced, namely the LQ 45 Index. The LQ 45 index is a stock index of 45 shares of public companies that can be traded on the Indonesia Stock Exchange (BEI).

This index includes 45 of the most liquid stocks, namely having a high level of trading transactions and having a large market capitalization value and since July 13, 1994. This index is determined to have an index value calculation of 100 as the base value.

\section{METHOD}

In this study, the method used is a descriptive method with a quantitative approach. Descriptive method is a problem formulation that deals with the question of the existence of independent variables, either only on one or more variables. The verification method is a research method through proving to test the hypothesis of descriptive research results with statistical calculations in order to obtain the evidentiary results that indicate the hypothesis is rejected or accepted. The quantitative method is a research method based on the philosophy of positivism, which is used to examine a population or a particular sample, data collection using research instruments, data analysis is quantitative / statistical, with the aim of testing predetermined hypotheses.

The population in this study were companies listed in the LQ45 index based on the statistical reporting period of the Indonesian Stock Exchange from August 2019 to January 2020. In this study the sampling criteria were based on companies registered during the study period. The samples in this study were companies that remained on the IDX statistical reports from August 2019 to January 2020, namely 45 samples.

In this study, there are three variables that become independent variables, namely Monday Effect (X) and Stock Return (Y) which is the dependent variable. The variables in question are as follows:

Independent Variable (X)

The independent variable is anything in the form determined by the researcher starting from studying so that information is obtained about it, and then the conclusion is drawn.

Monday Effect is a season anomaly (seasonal anomaly) or calendar effect that occurs in financial markets, when stock returns are significantly negative on Monday.

How to calculate the actual daily return:

R Monday $=($ Share Price Monday-Share Price Friday $) /($ Share Price Friday $)$ 
R Tuesday $=($ Share Price Tuesday- Share Price Monday $) /($ Stock Price Monday $)$

R Wednesday $=($ Share Price-Tuesday Share Price $) /($ Share Price Wednesday $)$

R Thursday $=($ Share Price Thursday-Share PriceWednesday) $/$ (Share PriceWednesday)

R Friday $=($ Share Price Friday-Thursday Share Price $) /($ Share Price Thursday $)$

2. The stock return is then averaged each day, which in the end is the daily stock return value for one year

b. Dependent Variable (Y)

The dependent variable in this study is stock return as (Y). Return of shares is the return of ordinary shares, and is a cash payment received as a result of owning a share. In this study, the actual return is obtained from the daily closing price of shares during the study period. Return is expressed in the following equation. The formula for calculating stock returns is

$\mathrm{Rt}=(\mathrm{Pt}-\mathrm{Pt}-1) /(\mathrm{Pt}-1)$

Information:

$P t=$ stock closing price at the end of period $\mathrm{t}$

$P t-1=$ closing price at the end of period $\mathrm{t}-1$

From the explanation above, the independent and dependent variables used in the study were entitled

"Analysis of Monday Effect on LQ 45 Company Stock Returns on the Indonesia Stock Exchange (BEI).

\section{Data collection technique}

Quantitative data is a research method that is based on the philosophy of positivism, used to examine specific populations or samples, data collection using research instruments, statistical data analysis with the aim of testing hypotheses. The data required for this study were obtained from companies on the LQ45 Index listed on the Indonesia Stock Exchange from August 2019 to January 2020. In this study the data is secondary data because data is obtained by taking data from the Indonesia Stock Exchange (IDX) via the internet on the website. Indonesia Stock Exchange (www.idx.co.id)

\section{Methods of Analysis and Hypothesis Testing}

The data analysis method is a way to group data based on variables, tabulate data based on variables, present data for each variable under study, and perform calculations to answer problem formulations, and perform hypothesis testing.

Data analysis method

Data analysis method is an activity after data from all respondents or other sources have been collected. In this study, the data analysis technique used descriptive analysis. Data processing tools in this study used Microsoft Office Excel and SPSS applications.

Descriptive statistics are statistics that are used to analyze data by describing or describing the collected data as is without the intention of making generalized conclusions or generalizations. Data analysis in the form of descriptive statistics is the presentation of data through tables, graphs, diagrams, circles, pictograms, mode calculations, media, mean, decile calculations, percentiles, calculation of data distribution through calculating the average and standard deviation.

Descriptive analysis aims to provide an explanation of the variables to be observed. Analysis of the ratios to find the numbers of the variable X (Monday Effect) and Variable Y (Stock Return).

\section{Partial Signification Test (T Test)}

The $t$ statistical test is also called the individual significance test. This test the effect of the independent variable partially on the dependent variable. In the end, a conclusion is drawn that Ho is rejected or $\mathrm{H} \alpha$ is accepted from the formulated hypothesis. Significant test of the hypothesis that has been determined using the $t$ test. The formula for testing the $t$ test is as follows:

$\mathrm{t}=(\mathrm{r} \sqrt{ } \mathrm{n}-2) /(\sqrt{ } 1-\mathrm{r} 2)$

Information:

$\mathrm{t}$ : Test Value $\mathrm{t}$

r: Correlation coefficient

This publication is licensed under Creative Commons Attribution CC BY. 
$\boldsymbol{r}^{2}$ : The coefficient of determination

$\mathrm{n}$ : Number of samples

The $t$ test uses several basic analyzes to determine the influence and relationship of the variables. The following is the basis of the analysis used in the $t$ test:

1. Comparison of $t$ count with $t$ table

a. If $\mathrm{t}<\mathrm{t}$ table or if -thitung $>-\mathrm{t}$ table then Ho is accepted and $\mathrm{H} \alpha$ is rejected.

b. If $t$ count> $t$ able or if -thitung <-t table then Ho is rejected and $\mathrm{H} \alpha$ is accepted.

2. Comparison of significance value with real level

a. If the significance value $>$ real level $(0.05)$, then Ho is accepted and $\mathrm{H} \alpha$ is rejected.

b. If the significance value < real level (0.05), then Ho is rejected and $\mathrm{H} \alpha$ is accepted.

Partial test ( $T$ test) is used to test whether there is an effect of the independent variable on the dependent variable partially. Testing of the regression results was carried out using the test at the degree of confidence of $95 \%$ or $\alpha=5 \%$.

The steps for determining it are as follows:

Create a hypothesis testing formula

$\mathrm{H} 0: \beta 1=0$, there is no effect of Monday Effect on the LQ45 index stock return.

$\mathrm{H} 1: \beta 1 \neq 0$, there is an effect on the Monday Effect on LQ45 stock returns

1. Determine the level of significance

2. The criteria for making the $\mathrm{T}$ test decision in this study with a Probability value can be described as follows

a. If the Probability value $>\alpha(5 \%)$, then $\mathrm{H} 0$ is accepted.

b. If the Probability value $<\alpha(5 \%)$, then $\mathrm{H} 0$ is rejected.

3. Withdrawal of conclusions

Based on the results of hypothesis testing and supported by theories from experts, a conclusion is drawn. It is hoped that after carrying out these stages, the right conclusions can be drawn.

\section{RESULTS AND DISCUSSION}

\section{Overview of Research Objects}

In February 1997 the LQ45 index was launched for the first time, but in order to obtain longer historical data, the base day used was July 13, 1994, with an index value of 100.The LQ45 index is 45 issuers that have gone through a selection process with high liquidity (liquid) and other criteria. These criteria may include market capitalization considerations. The number of 45 issuers is adjusted every six months, namely at the beginning of February and August. So the list of stocks contained in LQ45 will always change. The main measure of transaction liquidity refers to the transaction value on the regular market. Due to market developments and sharpening liquidity criteria, in January 2005 the number of trading days and frequency of transactions were included as a measure of liquidity. The criteria for a stock to be included in the LQ45 index are as follows:

1. At least 3 months listed on the IDX

2. Financial condition, growth perospec, and high transaction value

3. Entered into 60 shares based on transaction value on the regular market in the last 12 months

4. Entered the 60 stocks with the highest capitalization in the last $1-2$ months

5. Then from the 60 stocks, the top 30 stocks will be automatically included in the LQ45 index calculation.

Table of Company Industry Scores on the LQ 45 Stock Index for the period August 2019 to January 2020

\begin{tabular}{cccc} 
No & Sector & Total & Percentage \\
\hline 1 & Property & 2 & $4 \%$
\end{tabular}




\begin{tabular}{llcc}
2 & Misc Industry & 2 & $4 \%$ \\
\hline 3 & Property \& Construction & 4 & $9 \%$ \\
\hline 4 & Infrastructure \&Transportation & 5 & $11 \%$ \\
\hline 5 & Trade, Service \& Investment & 6 & $13 \%$ \\
\hline 6 & Finance & 6 & $13 \%$ \\
\hline 7 & Mining & 6 & $13 \%$ \\
\hline 8 & Consumer Goods & 6 & $13 \%$ \\
\hline 9 & Chemical Industry & 8 & $18 \%$ \\
\hline & Total & $\mathbf{4 5}$ & $\mathbf{1 0 0 \%}$
\end{tabular}

From table, the largest number of companies in the checmical industrial sector is on the LQ 45 stock index, namely 8 companies and the least number of companies is in the property and misc industry, namely two companies each

This research requires descriptive analysis to describe the daily stock return data of LQ 45 in the period August 2019 to January 2020. So to find out, the average value (mean), minimum value and maximum value are calculated, as well as the data standard deviation. Description of average return Monday to Friday. To test the difference in return that occurs on Monday to Friday, it is done. The return description Monday to Friday can be seen in the following table:

Table of LQ 45 Company Shares Returns in August 2018 to January 2020

\begin{tabular}{llclll} 
No & $\begin{array}{l}\text { Day } \\
\text { Trading }\end{array}$ & Min & Max & Rata-Rata & $\begin{array}{l}\text { Std } \\
\text { Deviasi }\end{array}$ \\
\hline 1 & Monday & $-0,96046$ & 0,124646 & $-0,00428$ & 0,04991 \\
\hline 2 & Tuesday & $-0,90035$ & 0,244216 & $-0,00001$ & 0,047793 \\
\hline 3 & Wednesday & $-0,39139$ & 0,107383 & $-0,00134$ & 0,025313 \\
\hline 4 & Thursday & $-0,13525$ & 0,169675 & $-0,00122$ & 0,022124 \\
\hline 5 & Friday & $-0,84606$ & 0,484733 & $-0,00008$ & 0,046108
\end{tabular}

up to 0.0124646 , with an average return of -0.0048 . This means that on Monday most of the stock returns have increased. The data in Table 2 also shows that on Tuesday the average return ranged from -0.9003 to 0.244216 , with an average return of -0.00001 . This means that on Tuesday most of the stocks increased. On Wednesday the average return ranges from -0.39139 to 0.1073 with an average return of -0.00134 . On Thursday the average return ranges from -0.13525 to 0.16967 with an average return of -0.00122 . On Thursday the average return ranges from -0.84606 to 0.484733 with an average return of -0.00008

Based on the average return data, it is then used to test the hypothesis. This hypothesis testing is done by using one sample $t$ test (one sample $t$ test). Based on the results of the one sample $t$ test (one sample $t$ test), it can be seen that the $t$ value is -3.322 . The value of $t$ table at 95 percent confidence level and degrees of freedom ( 45 companies $x 5$ days $-1=224$ ) is 1.651 . So the value of $t$ count $>t$ table, or $t$ count is in the rejection area $\mathrm{HO}$ or the acceptance area $\mathrm{Ha}$. This means that there is no significant difference between daily stock returns on trading days in one week on the Indonesia Stock Exchange. Thus the hypothesis which 
states that there is a significant difference between daily stock returns on trading days in one week on the Indonesia Stock Exchange is rejected.

Based on the value of the standard deviation, the largest occurred on Monday, namely 0.04991. This means that Monday has the highest risk when compared to other days. Meanwhile, the lowest standard deviation occurred on Thursday, namely 0.002124 which means the smallest risk compared to other days. Monday effect occurs on Monday. Monday effect is used to test the Monday effect on stock trading on the Indonesia Stock Exchange which results in negative stock returns at the beginning of the week. The following results of the Monday effect calculation can be seen in the following table:

The Monday Effect Calculation Result Table

\begin{tabular}{lll} 
No & $\begin{array}{l}\text { Hari } \\
\text { Perdagangan }\end{array}$ & Rata-Rata \\
\hline 1 & Senin & $-0,00428$ \\
\hline 2 & Selasa & $-0,00001$ \\
\hline 3 & Rabu & $-0,00134$ \\
\hline 4 & Kamis & $-0,00122$ \\
\hline 5 & Jumat & $-0,00008$
\end{tabular}

Based on the table above, it is known that the average return on Monday is -0.00428 . This shows that stock returns on Monday tend to be negative or there is a decline in stock returns on Monday with an average of 0.00428. This means there is a Monday effect on stock returns on the Indonesia Stock Exchange.

\section{CLOSING}

Conclusion

1. There is no significant difference between stock returns on trading days in one week on the Indonesia Stock Exchange from August 2019 to January 2020. This is evidenced by one sample t-test analysis with a significant level of $-0.427 \%$. Thus the hypothesis which states that there is a difference in stock returns on Monday to Friday in the Indonesia Stock Exchange is rejected.

2. There is a Monday effect on stock trading on the Indonesia Stock Exchange which results in negative stock returns at the beginning of the week for the period August 2019 to January 2020. This is evidenced by the results of descriptive analysis where the average return on Monday is negative. Thus the hypothesis which states that a Monday effect occurs on stock trading on the Indonesia Stock Exchange is accepted.

Suggestion

1. For company management, pay more attention to conditions in the capital market in making decisions.

2. For investors, pay attention to the phenomena found in the capital market and have accuracy when trading the stock market because in this study the lowest return does not only occur on Monday.

3. Researchers can increase their observation time in order to obtain a more comprehensive picture of market reactions.

\section{REFERENCES}

Anoraga, Pandji dan Piji Pakarti. (2006). Pengantar Pasar Modal. Edisi Revisi. Rineka Cipta. Jakarta.

Ardinan, Haikel .2014. Pengujian Monday Effect pada Bursa Efek Singapura, Journal of Business and Banking Vol. 4. No.1. May 2014. hal: 81-90. 
Arief, Adhie Kurniawan .2012. Analisis Pengaruh hari perdagangan terhadap Return saham Perusahaan Bidang Telekomunikasi yang terdaftar di Bursa Efek Indonesia pada tahun 2011, Jurnal Riset Akuntansi Keuangan, Vol. 12, No. 1, Februai 2016.

Ary, Tatang Gumanti. 2011. Manajemen Investasi - Konsep, Teori dan Aplikasi. Mitra Wacana Media, Jakarta.

Asfia Murni. 2013. Ekonomika Makro. PT Refika Aditama.Bandung.

Azis, Anton Mulyono dan Maya Irjayanti. (2014). Manajemen. Mardika Group. Bandung.

Azis, Musdalifah. 2015. Manajemen Investasi Fundamental. Teknikal. Perilaku Investor dan Return Saham. Deepublish. Yogyakarta.

Budileksamana, Antariksa. 2010. Fenomena The Monday Effect di Bursa Efek Indonesia. Jurnal, SNA VII Solo.

Bungin, Burhan. 2017. Metodologi Penelitian Kuantitatif. Edisi 2. Kencana. Jakarta.

Brigham, Eugene F and Joel F.Houston. 2006. Dasar-Dasar Manajemen Keuangan. alih bahasa Ali Akbar Yulianto, Buku satu, Edisi sepuluh, PT. Salemba Empat. Jakarta.

Basuki, Agus Tri dan Nano Prawoto. (2017). Analisis Regresi Dalam Penelitian Ekonomi dan Bisnis: Dilengkapi Aplikasi SPSS \& EVIEWS. Edisi Kedua. PT Rajagrafindo Persada. Depok.

Budileksmana, Antariksa. (2013). Pengujian Monday, Friday dan Earnings Management Effect Terhadap Return Saham. Jurnal Keuangan dan Perbankan, Vol. 13. No.1 Februari 2013. hal. 1 - 16.

Cahyaningdiyah. 2012. Analisis Monday effect dan Weekend effect pada return saham perusahaan LQ 45 di BEI periode 2010-2011. Perusahaan yang Terdaftar pada Bursa Efek Indonesia. Jurnal Keuangan. Universitas Sumatera Utara.

Carlucci et al .2014. The Weeksday Effect Anomaly In The Behavior Of Stock Index Returns Of Brazil, Mexico And USA, Business and Management Review Vol. 3 .9. July 2014. pp. 31-38.

Caporale et al .2015. The Weekend Effect. An Exploitable Anomaly In The Ukranian Stock Market. DIW Discussion Paper. No. 145.

Darmadji \& Fakhrudin. (2010). Pasar Modal di Indonesia: Pendekatan Tanya Jawab. Jakarta: Salemba Empat

Eun, C.S., Resnick, B.G., dan Sabherwal. 2014. Keuangan Internasional. Salemba Empat. Jakarta.

Pendidikan Ganesha. Bali.

Gumantri. 2011. Manajemen Investasi - Konsep. Teori. Aplikasi . Mitra Wacana Media. Jakarta.

Harsono, Budi. 2013. Efektif Bermain Saham. PT. Elex Media Komputindo. Jakarta.

Mahd, Ansyori. 2010. Studi Tentang Pengaruh Hari Perdagangan terhadap Return Saham

Lutfi, Aji, Djazuli Atim. (2014). Pengujian The Day of The Week Effect, Week Four Effect, dan Rogalsky Effect terhadap Return Saham LQ-45 di Bursa Efek Indonesia. Jurnal Ilmiah Mahasiswa FEB Vol 2. No 1: Semester Ganjil 2013/2014. Publisher. Fakultas Ekonomi dan Bisnis Universitas Brawijaya.

Muniya, Alteza, (2007). Efek Hari Perdagangan Terhadap Return Saham: Suatu Telaah atas Anomali Pasar Efisien. Jurnal Ilmu Manajemen. Volume 3.Nomor 1. Hal 36-37.

Muliyani, Bambang. 2014. Berani Untung di Bursa Saham. PT Elex Media Komputindo. Jakarta.

Qurira Octaviano, Danes dan I Wayan Nuka Lantara .2014. Market Overreaction. Size atau Liquidity Terhadap Return Saham Studi pada Bursa efek Indonesia. Pengujan Menggunakan GARCH. Jurnal Manajemen dan Bisnis. Vol. 1. No.1. Hal. 1-100

Robert, Ang. (2000). Buku Pintar Pasar Modal Indonesia (The Intelligent Guid to Indonesian Capital Market). Mediasoft Indonesia. pada BEJ. Jurnal Akuntansi dan Keuangan, Vol. 8. No. 2. November 2006: 63-70.

Sularso,Havid, Drs M.M.,Ak, Dr Eko saryono dan Dwi Rahmawanto .2011. Analisis Monday effect dan Weekend effect pada return saham LQ45.Vol.8 No.1. Februari 2011. Fakultas Ekonomika dan Bisnis Universitas Gadjah Mada. Yogyakarta-Indonesia.

Werastuti, Desak Nyoman Sri. 2012. Anomali Pasar Pada Return Saham The Day Of Week Effect, Week Four Effect, Rogalsky Effect, dan January Effect. JurnaI Ilmiah Akuntansi dan Humanika. Volume 2 Nomor 1. Edisi Desember 2012. Universitas

Yani, Aulia Rahma. 2014. Pengujian January Effect dan Size Effect Terhadap Return Saham. Jurnal Keuangan dan Perbankan, Vol. 13 No.1 Januari 2014.hal. 1 - 18. 